\title{
Reception Écrite Teaching and Learning Model Based on Multiliteracies Approach (A Strategy in Improving Students' Multiliteracies)
}

\author{
Irwandy $^{1}$, Elvi Syahrin ${ }^{2}$, Pengadilan Sembiring ${ }^{3}$ \\ \{ irwandymanday@gmail.com ${ }^{1}$ \} \\ Faculty of Languages and Arts, Universitas Negeri Medan, Indonesia ${ }^{1,2,3}$
}

\begin{abstract}
The twenty-first century life demands the mastery of various twenty-first century skills. Therefore there is a need for learning innovation that can enhance the mastery of students' multiliteracies in a specific learning process. Teaching multiliteracies in a learning process requires a teaching model, in which several literacies could be taught synergistically and systematically. Multiliteracies is a skill in using various methods to understand concepts and information by using various kinds of texts whether conventional or innovative, symbols, and multimedia. Multiliteracies is also considered as the ability to view learning integratively, thematically, multimodally, and interdisciplinarily. In this case, academic language plays an important role in the teaching and learning process. Consequently, the students are expected to be able to master academic language and literacy properly. Because of the importance of multiliteracies mastery, and in order to simplify Reception Écrite teaching and learning process, Reception Écrite teaching and learning model based on multiliteracies approach will be developed in this study. The study aims to obtain a good quality Reception Écrite teaching and learning model based on multiliteracies approach. In line with the purpose, there will be a developmental research with reference to the concepts of development by Plomp (1997), which are (1) investigation, (2) design, (3) realization/construction, (4) test, evaluation, and revision and (5) implementation.
\end{abstract}

Keywords: Teaching and Learning Design, Production Écrite, Twenty-First Century.

\section{Introduction}

The ability to speak French of the students of French Language Education Study Program at the State University of Medan (UNIMED) is still not so good yet. Based on the data obtained from the study program, the graduates who received DELF B2 international certificate is just $10 \%$. This has been a serious problem that must be solved sooner than later. On the other hand, there is a demand of life in the twenty-first century which requires the mastery of multiliteracies. Therefore, learning must facilitate students to master multiliteration wherever possible.

To date, French learning in the French Language Education Study Program at UNIMED was carried out partially through grouping of four main courses, namely (1) reception orale, (2) reception écrite, (3) production orale, and (4) production écrite. On the one hand, this separation can focus more on one particular language skill, while on the other hand this separation often results in overlapping materials because the books used are the same. This 
separation also affects the difficulty of choosing the right learning model in accordance with the characteristics of the four subjects of language skills. In line with this, it is necessary to develop appropriate learning models to teach all four French language skills and other literacy. Learning models that are considered appropriate are learning models based on multiliteration learning approaches.

Multiliteracies is the skill of using various ways to express and understand ideas and information using conventional text forms as well as innovative text, symbols and multimedia. From multiliteracies perspective, students need to be experts in understanding and using various forms of text, media, and symbol systems to maximize their learning potentials, follow technological changes, and actively participate in global communication. Thus, multiliteracies learning is aimed at developing students' skills in critical literacy, visual literacy, media literacy, technology literacy, cross curriculum literacy, and literacy in other languages (Abidin, 2015: 51).

Luke (Kist, 2005: 41) states that multiliteracies is the ability to view knowledge (learning) in an integrative, thematic, multimodal, and interdisciplinary manner. In this case academic language plays a very important role in the learning process. In line with this reality, students are required to be able to master academic language and literacy competently (Abidin, 2015: 53)

The formulation of the research problem is how the process and the results of developing the Reception Écrite Learning Model Based on Multiliteracies Learning Approach are of good quality? The study aims to produce a Reception Écrite Learning Model Based on Multiliteracies Learning Approach of good quality.

\section{Method}

The object of this research is the development of Reception Écrite Learning Model Based on Multiliteracies Learning Approach (MP-REBP2M). The data that will be collected, namely (1) data on the process of developing Reception Écrite Learning Models Based on Multiliteracies Learning Approaches, and (2) the quality of the Reception Écrite Learning Model Based on Multiliteracies Learning Approaches in terms of validity, practicality, and effectiveness. This research will use a developmental research approach, based on Plomp's (1997) development theory, which consists of: (1) investigation phase, (2) design phase, (3) realization/construction phase, (4) test, evaluation, and revision phase, and (5) implementation phase.

In the investigation phase, researchers will conduct an in-depth study of the things needed to carry out the development of the Reception Écrite Learning Model Based on the Multiliteracies Learning Approach. This study includes analysis of documents related to research needs, analysis of student needs, and analysis of lecturer needs in learning.

In the design phase, the design of the Reception Écrite Learning Model Based on the Multiliteracies Learning Approach will be carried out. The design of this model is in the form of learning model and specifications.

In the construction phase, the learning model will be developed based on the format and specifications of the learning model.

In the test, evaluation, and revision phase, experts will evaluate the learning model that has been developed, and continue with revisions based on input from the experts. This process will run continuously until a valid learning model is obtained. 
After obtaining a valid learning model, it will proceed with the implementation phase. In this phase the product development test will be conducted in the trial class.

Data on the process of developing a learning model will be obtained through observation by researchers. Data validity of learning models will be obtained through experts' judgments. Data on the practicality of the learning model will be obtained through the assessments of students and instructors on the learning model. Data on the effectiveness of the learning model will be obtained by comparing the results of the pretest with the posttest.

Data about the learning design development process will be analyzed descriptively qualitative. Data on validity, practicality, and effectiveness of learning design will be analyzed quantitatively and qualitatively.

\section{Theoritical Framework}

The world of work in the 21 st century requires mastery of four groups of skills, namely (1) thinking skills, (2) working skills, (3) using tools to work skills, and (4) life skills (Binkley, et al. 2012: 18-19). The four groups are developed into ten competencies, namely (1) critical thinking, problem solving, and decision making, (2) meta-cognition, (3) creativity and innovation, (4) collaboration, (5) communication, (6) life and career, (7) information literacy, (8) information and communication technology literacy, (9) citizenship attitude, and (10) personal and social responsibilities.

There are four characteristics of 21 st century learning, namely (1) information, (2) computing, (3) automation, and (4) communication (Abidin, 2015: 102-103). The first characteristic of 21 st century learning is the characteristic of information where learning must encourage students to find out, not be told. This feature is in line with the Constructivism theory which views that knowledge is the result of cognitive construction through one's activities. Humans construct their knowledge through interaction with objects, phenomena, experiences, and their environment (Paul Suparno, 1997).

The second characteristic, which is computing, is where work can be completed more quickly and precisely using computer technology. Fatima Pirbhai - Illich, K.C. Nat Turner, and Theresa Y. Austin, (2009) in their research states that digital literature as a multiliteracies section needs to be developed in the context of teaching where learning is demanded by many factors. The inclusion of a digital curriculum provides greater possibilities for academic success for students who are marginalized in mainstream schools and alternative schools.

The third characteristic, which is automation, is that all dimensions of life can be controlled automatically. Learning must be able to foster students to think critically. This critical thinking ability is part of higher order thinking skills that must be trained in learning.

The fourth characteristic is communication, where learning must be able to practice communication and collaborative skills. Kenneth David Strang (2015) in his research states that business schools and other disciplines can apply collaborative learning models to help students improve exam results, reduce differences in views regarding gender, age, and ability.

In line with the paradigm and characteristics of 21 st century learning, a learning model is needed that can develop students' multiliteracies. Learning must be able to integrate various literacies needed in a learning process. In learning French, for example, to learn listening skills must involve other language skills. Furthermore, if the listening learning activity uses technology as a learning medium, it means that technological literacy has been developed in the learning process. In connection with this, and to optimize learning outcomes, a multiliteracies approach based learning model is needed. 
Before discussing the concept of multiliteracies, we will first discuss the concept of literacy. Literacy is traditionally considered as the ability to read and write. Along with the passage of time, the concept of literacy has expanded to various other important fields. The concept of literacy has undergone five phases of development. In the early generation literacy was only defined as the ability to use language and images for reading, listening, speaking, writing, seeing, presenting, and thinking critically about ideas. In the second generation, literacy was related to the situation and social practice. Literacy was considered as a cultural belief and habit. In the third generation, literacy experienced a growing of understanding of the rapid progress of information and multimedia technology. In the fourth generation, it was seen as a social construction and was never neutral. In the fifth generation, the term literacy is better known as multiliteracies where literacy has covered various fields of life (Abidin, 2015: 50-51).

Multiliteracies is a way of understanding more broadly the literacy curriculum learned in the world of formal education so that students are able to participate productively in society (Baguley, et al., 2010). Conceptually, multiliteracies is a design that can be used to understand various types of texts and media through pedagogic concepts to make it easier for teachers to present information using text and media. With the learning based on multiliteracies learning model approach, learning activities will become more effective and efficient (Cope and Kalantzis, 2005). Furthermore, Iyer and Luke (2010) states that students who learn to use multiliteracies approach will gain a higher understanding.

To be able to better implement the multiliteracies learning approach in Reception Écrite learning, a multiliteracies learning approach based learning model is needed. The learning approach does not provide a clearer description of the learning syntax, social system, support system, and instructional impact and impact of learning accompaniment.

Learning model is a plan or a pattern that is used as a guideline in planning learning in class or in tutorial activities (Joice \& Weil, 1992: 4). It is used to determine learning devices, and serves as a guide for teachers in designing learning. Eggen (1996: 11) states that learning model is a learning perspective strategy designed to achieve learning goals.

The opinions stated above clearly state that learning model is a learning perspective strategy in which it describes systematic procedures in regulating learning activities, and serves as a means to achieve learning goals. A learning model will largely determine what learning tools are needed to achieve the learning objectives set.

A learning model can be analyzed based on five operational core concepts of learning models namely: (1) syntax, (2) social systems, (3) reaction principles, (4) support systems, and (5) instructional and accompanying effects (Joice \& Weil, 1992: 13-16).

Syntax is the phases or steps of the activities of the model which is a series of learning activities. The learning syntax shows the activities that need to be done by lecturers and students during learning activities. The social system is the situation or atmosphere and the norms that apply in the model. The principle of reaction is the way lecturers view and respond to what students do. The support systems are means, infrastructure, learning materials, and tools needed to implement the model. Instructional and companion impacts are learning outcomes that are achieved directly by directing students to the expected goals. To be able to develop the Reception Écrite learning model based on multiliteracies learning approach, a conceptual framework is designed as follows. 


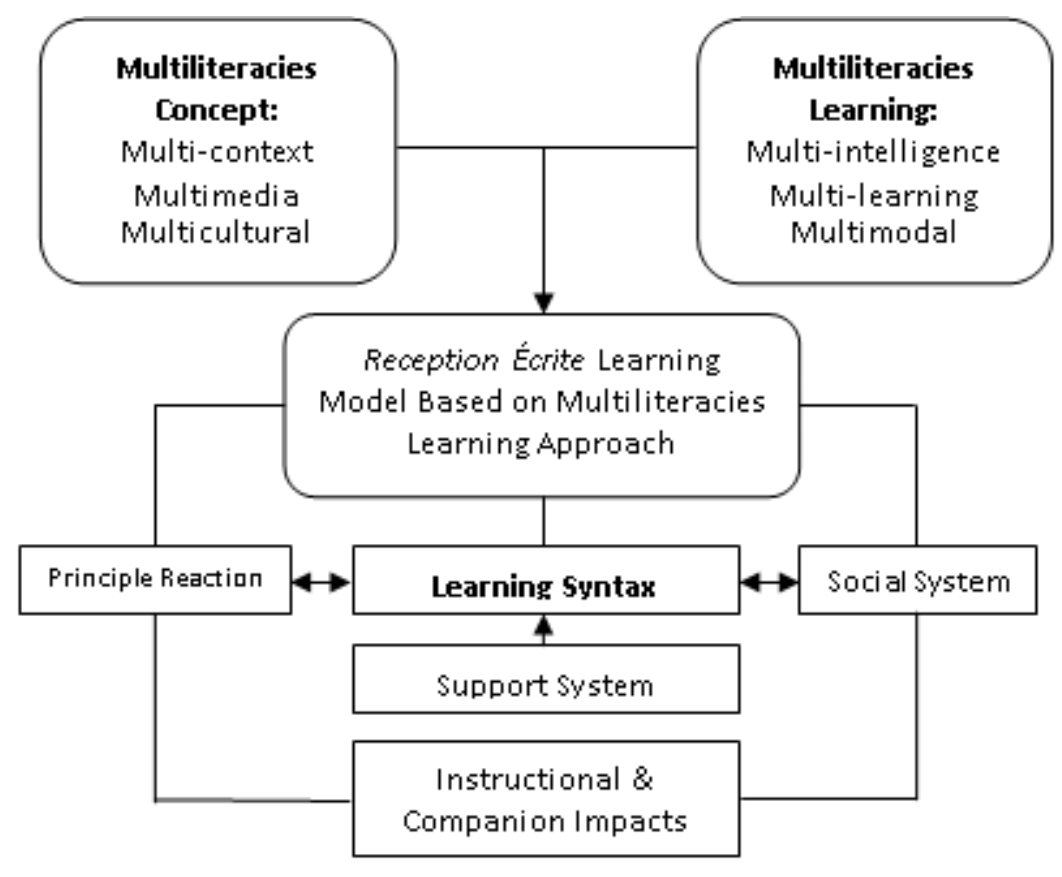

Figure1: Conceptual Framework for Developing Reception Écrite Learning Models Based on Multiliteracies Learning Approaches

In order for the concept of multiliteracies learning approaches to run well, it is necessary to integrate multiliteracies activities in reception écrite learning. This integration is in line with integrated learning theory developed by experts such as Joni (1996: 3) who states that integrated learning is a learning system that allows students, both individually and in groups, to actively explore and discover scientific concepts and principles holistically, meaningfully, and authentically. Integrated learning will occur if authentic events or exploration of topics or themes become controllers in learning activities. By participating in the exploration of the theme/event, students learn the process and contents of several subjects simultaneously. Integrated learning is also seen as learning that begins with a particular subject that is related to other subjects that are carried out spontaneously or planned, both in one field of study and with various learning experiences of students.

There are several theories that are in accordance with the principles of multiliteracies learning such as Piaget, Vygotsky, Constructivism, and John Dewey and Herbert Thelan theory. In Piaget's theory it is said that every child has an innate curiosity that drives him to interact with his environment. Piaget believes that physical work experience and environmental manipulation will develop his abilities. He also believes that social interaction with peers will clarify the results of his thinking more logically (Slavin, 2000: 32).

Reception Écrite Learning Model Based on Multiliteracies Learning Approach directs students to engage in task completion activities and problem solving in groups. The interaction between students is facilitated by the lecturer, allowing subjective knowledge that is built by each student to become objective knowledge. 
In Vygotsky's theory it is stated that the acquisition of "sign system" occurs in the sequence of invariant stages for each child as stated by Piaget. It's just that Vygotsky sees differently in the "triggers" of children's cognitive development. According to him, the child's cognitive development is very strong with input from other people. In connection with this, learning needs to be done cooperatively, and the importance of learning approaches that emphasize scaffolding (Slavin, 2000: 46-47).

Vygotsky's theory provides a strong foundation for the Reception Écrite Learning Model Based on Multiliteracies Learning Approach. Students will be grouped into several groups with heterogeneous backgrounds. They are trained to interact, work together, complement each other, and help each other. For underprivileged students will get guidance from capable students, and also guidance from lecturers.

Constructivism theory considers that knowledge is the result of cognitive construction through one's activities (Paul Suparno, 1997). In learning to use the Reception Écrite Learning Model Based on Multiliteracies Learning Approach, the knowledge gained by students is not obtained passively (transferred from lecturers), but is actively constructed by the students themselves. The results of individual construction and group construction still need to be discussed in class to obtain objective knowledge.

The theory of John Dewey and Herbert Thelan states that lecturers need to create a social system characterized by democracy and scientific processes in the classroom learning environment. The responsibility of the lecturer is to motivate students to learn cooperatively and think about social problems every day. Classes must be used as a miniature of democracy that aims to examine social and interpersonal problems (Arends, 1997: 112).

In the Reception Écrite Learning Model Based on Multiliteration Learning Approach, the concept of John Dewey and Herbert Thelan is seen in the heterogeneous members of student learning groups. Students will discuss to explore learning materials and conduct critical reading activities.

\section{Conclusion}

The world of work in the 21 st century requires the mastery of four groups of skills, namely (1) skills in ways of thinking, (2) skills in how to work, (3) skills to use tools to work, and (4) life skills. To be able to reach these four skill groups, learning innovation is needed that can develop multiliteracies on students. One form of learning innovation in question is to develop a reception écrite learning model based on a multiliteracies approach.

Reception écrite learning model based on a good multiliteracies approach must include five components of learning model, namely (1) syntax, (2) social systems, (3) reaction principles, (4) support systems, and (5) instructional and accompanying effects. In these five components there must be a learning process that trains students' multiliteracies skills.

\section{References}

[1] Abidin, Y.: Pembelajaran Multiliterasi. PT Refika Aditama, Bandung (2015)

[2] Arends, R.I.: Classroom Instruction and Management. Mc Graw Hill, Albany (1997)

[3] Baguley, Pullen, \& Short. Multiliteracies and the New World Order. In Pullen \& Cole (Eds.). Multiliteracies and Technology Enhanced Education: Social Practice and Global Classroom. Information Science, New York. Reference (an imprint of IGI Global). (2010) 
[4] Binkley, M., et al.: Defining Twenty-First Century Skills. In Griffin, P., Assessment and Teaching of 21 st Century Skills. Springer, New York (2012)

[5] Cope and Kalantzis.: Multiliteracies: Literacy Learning and The Design of Social [6] Futures. Routledge, Taylor \& Francis Group, New York (2005)

[6] Eggen, P.D., Kauchak, D.P.: Strategy for Teacher: Teaching Content and Thinking Skills. 3rd Edition. Allyn \& Bacon, USA. (1996)

[7] Iyer, R., Luke, C.: Multimodal, Multiliteracies: Texts and Literacies for 21st Century. In Pullen \& Cole (Eds.). Multiliteracies and Technology Enhanced Education: Social Practice and Global Classroom. Information Science Reference (an imprint of IGI Global), New York (2010)

[8] Joni, R.T., et al.: Materi Pokok Pembelajaran Terpadu S2 Pendidikan Dasar. Depdikbud, Jakarta (1996)

[9] Joyce, B., Weil, M.: Model of Teaching. Allyn and Bacon Publishing Company, Massachussents (1992)

[10] Strang, K.D.: Effectiveness of instructor-led collaborative learning in the classroom. Journal of Applied Research in Higher Education. pp.134-145 (2015)

[11] Kist, W.: New Literacies in Action: Teaching and Learning in Multiple Media. Teachers College Columbia University, New York (2005)

[12] Pirbhai-Illich, F., Turner, K.C., Austin, T.Y.: Using digital technologies to address Aboriginal adolescents' education: An alternative school intervention". Multicultural Education \& Technology Journal. pp.144-162, (2009)

[13] Plomp, T.: Educational \& Training System Design. Introduction. University of Twente, Faculty of Educational Science and Technology Enschede, Enschede (1997)

[14] Slavin, R.E.: Educational Psychology: Theory and Practice. Allyn \& Bacon Publisher, Boston (2000)

[15] Suparno, P.: Filsafat Konstruktivisme dalam Pendidikan. Kanisius, Yogyakarta (1997) 